\title{
パルプ廃水の清水化に関する研究 クラフトパルプ廃水の活性炭吸着プラント試験*
}

四国工業技術試験所 壁谷 洋，藤井利郎，木村 裕

\section{Studies of Renovation of Pulp Mill Wastewater Pilot Plant Tests for Granular Activated Carbon Adsorption of Kraft Pulp Mill Wastewater}

\author{
Hiroshi Kabeya, Toshiro Fujii and Yutaka Kimura \\ Government Industrial Research Institute, Sikoku
}

\begin{abstract}
Lime-treated water of unbleached kraft pulp wash wastewater (lignin concentration 12 26 ppm, COD 25 44 ppm) and pretreated water of bleached kraft pulp caustic soda extract wastewater (lignin concentration $33 \sim 120 \mathrm{ppm}$ ) treated by activated sludge, followed by lime were offered the pilot plant tests for adsorption on granular activated carbon and the possibility of renovation of these treated waters was investigated.

Adsorption isotherms of several wastewater samples includiug treated waters were simultaneously determined and the relationship between adsorption isotherm and the carbon usage obtained from plant tests was developed.
\end{abstract}

At a superficial velocity of $1.7 \mathrm{~m} / \mathrm{hr}$ and contact time of $140 \mathrm{~min}$, the carbon usages of lime-treated water were $3,530 \mathrm{l} / \mathrm{kg}$-air-dried carbon on the basis of lignin breakthrough curve and $3,090 \mathrm{l} / \mathrm{kg} \cdot$ air-dried carbon on the basis of COD breakthrough curve. In order to examine the effect of lime treatment for wash wastewater, dilute water of wash wastewater equal to lignin concentration of lime-treated water was prepared and offered the pilot plant test in the same condition as lime-treated water. The carbon usages on the basis of lignin and COD were 310 and $3,670 \mathrm{l} / \mathrm{kg} \cdot$ air-dried carbon respectively.

From these results, it is apparent that the adsorption of lignin on activated carcon by lime treatment increases but the adsorption of COD hardly increases. These results are consistent with the results obtained from adsorption isotherms of lime-treated water and dilute water.

Similarly, the carbon usage of pretreated water of caustic soda extract wastewater was $130 \mathrm{l} / \mathrm{kg} \cdot$ air-dried carbon on the basis of lignin breakthrough curve. This small carbon usage mainly may be ascribed to high lignin concentration of influent because at the same initial lignin concentration adsorption capacity of pretreated water of caustic soda extract wastewater is rather larger than lime-treated water of wash wastewater.

\section{1. 緒言}

クラフトパルプ工場に物いては，現在，水質污濁防 止の観点吕ら, 凝集沈殿処理あるいは活性污泥処理が 実施ないしは検討されているが，これらのほとんどは 各パルプ工場の廃水が放流される河川あるいは海域へ の排出基準にしたがうように廃水を処理しようとする ものである。また，現在の技術水準では，凝集沈殿処 理あるいは活性污泥処理を単独をたは組み合わせるこ とによってパルプ廃水を処理しても, 有機物を完全に
除去することは困難である。

活性炭吸着法は，水中の微量有機污染物質を除去す るのに有効であり，これを上述の処理法と組み合わせ， パルプ廃水に適用させることによって，水質污濁防止 よりさらに進んだ用水化を行ない，将来の水不足に対 処することが必要と考完られる。

前報1,2) 飞招いて, クラフトパルプ廃水中の有機污 染物質の $50 \%$ 以上を占め，しばしば問題にされる色 の主成分と考穴られるリグニンを対象として，活性炭 吸着処理に関する基礎的な知見を得た。

*この報告を“活性炭によるパルプ廃水処理（第 3 報）”とする 
本報告は, クラフトパルプ工場廃水のらら, 未晒パ ルプ洗浄廃水（以下洗浄廃水とする）特よび晒アルカ リ抽出廃水号対象に，パルプ廃水の用水化の技術的， 経済的な問題点を検討するための基礎資料を得ること を目的とし，前処理（活性污泥処理, 消石灰処理）と 活性炭吸着処理を組み合わせ，中間プラント試験を行 なった結果について報告する。

洗浄廃水については，リグニン濃度 $70 \sim 100 \mathrm{ppm}$, COD 100 150 ppm, BOD $100 \mathrm{ppm}$ 以下の廃水を対 象にした。洗浄廃水の処理法としては，BOD 方比較 的低いので活性污泥処理を省略し，消石灰処理と活性 炭吸着処理を組み合わせた。また，消石灰処理の活性 炭吸着処理に特よぼす効果をみるため，洗浄廃水を消 石灰処理水のリグニン濃度と同じ程度になるように希 釈し, 希釈水について活性炭吸着処理を行なった。

つぎに，晒アルカリ抽出廃水については，リグニ ン濃度 $450 \sim 900 \mathrm{ppm}, \mathrm{COD} 500 \sim 1,000 \mathrm{ppm}$, BOD 200 400 ppm 程度の廃水を対象にした。晒アルカリ 抽出廃水の処理法としては, 活性污泥処理, 消石灰処 理，活性炭吸着処理を組み合わせた。なお，パルプ廃 水の活性活泥処理执よび消石灰処理については，それ

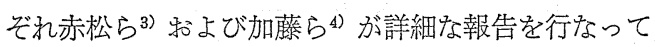
いる。

また，各廃水について，リグニン， COD 特よび TOC に基づいた見掛けの吸着等温線（10 日間吸着） 学求め，吸着等温線と活性炭吸着プラント試験の結果 の関連性について検討した。

\section{2. 実驗}

\section{1 試料}

\subsection{1 酒性崖}

前報2) と同じ 8 32 メッシュの国内産，市販粒状活 性炭を用い，吸着等温試験には，14〜20 メッシュの篩 別試料（粒子半径 $5.1 \times 10^{-2} \mathrm{~cm}$ ) を使用した。プラン 卜試験に供した 8 〜2 メッシュ活性炭の平均粒子半 径を粒径分布方ら求めると $5.6 \times 10^{-2} \mathrm{~cm}$ であり，吸着 試験に供する前に水洗を行ない微粉炭を除去した。

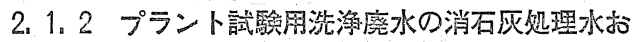 上び洗㴔廃水の希䣋水}

試験の都合上，クラフトパルプ黒液を水で希釈した ものを洗浄廃水とした。洗浄廃水中のリグニン濃度は 各工場によって異なることが予想されるが，本報告で はリグニン濃度を約 $80 \mathrm{ppm}$ に設定した。

この洗浄廃水を $300 \mathrm{l} / \mathrm{hr}$ の流量で当所の 石灰処理 装置に流し，消石灰学廃水 $1 l$ 当り $2 \mathrm{~g}$ の割合で添加 し，生成したスラッジを除去した後，スラリー循嘪型
凝集沈殿槽に咱き，炭酸ガスによる炭酸化を行ない， 溶解カルシウム分を㟶酸カルシウムとして沈降させ， 除去した処理水を砂沪過し，炭酸ガスにより $\mathrm{pH}$ 8.1 に調整した。この処理水（以下洗浄廃水の 前処理 水とする）を活性炭吸着プラント試験に供した。前処 理による結果の一例を Table 1 に示す。な特，連続 運転の期間中，前処理水のリグニン濃度和よび COD はそれぞれ 12〜26 ppm および 25〜44 ppm の範团 に変動した。

Táble 1 Lignin and COD removals for wash wastewater by lime treatment

\begin{tabular}{|c|c|cc|}
\hline & $\begin{array}{c}\text { Lignin } \\
\text { ppm } \begin{array}{c}\text { Removal } \\
(\%)\end{array}\end{array}$ & \multicolumn{2}{|c|}{ poD } \\
\hline $\begin{array}{c}\text { Original } \\
\text { wastewater } \\
\begin{array}{c}\text { Lime-treated } \\
\text { water }\end{array}\end{array}$ & 80 & 107 & \\
\hline
\end{tabular}

前処理の活性炭吸着に特よぼす效果を比較するため に，前処理水とリグニン濃度が等しいように希釈した 洗浄廃水（以下洗浄廃水の希釈水とする）を調製し， 炭酸ガスにより $\mathrm{pH}$ を 8.1 に調整した後，前処理水 と同じ条件でプラント試験を実施した。

\subsection{3 プラント試験用晒アルカリ掐出廃水の前処 理水}

晒アルカリ抽出廃水の前処理水は，クラフトパルプ 工場の晒工程から排出される一次のアルカリ抽出廃 水 (リグニン濃度 $450 \sim 900 \mathrm{ppm}, \mathrm{COD} 500 \sim 1,000$ ppm, BOD 200〜400 ppm) を中間プラント規模で活 性污泥処理した後，洗浄廃水の場合之同様に消石死好 理し，炭酸ガスで $\mathrm{pH}$ を8.1に調整した処理水であ り，これを活性炭吸着プラント試験に供した。

各処理による廃水のリグニン, $\mathrm{COD}$ 和よび BOD の変化の一例を Table 2 に示す。な和，連続運転の 期間中，前処理水のリグニン濃度は 33〜120 ppm の 範囲に変動した。COD については連続して測定しな かったが， Table 2 に示されるように前処理水の $\mathrm{COD}$ とリグニン濃度の比が㴗ぼ1であるので，COD の変㗢もリグニンと同じ範囲にあると推定される。

\section{1.4 吸着等温試驗用各種膊水}

活性炭吸着プラント試験の結果を解明するのに吸着 等温線が役立つと考えられる。本報告では，リグニン の活性炭に対する吸着性を検討することを目的とし， 各種廃水のリグニン濃度を同一にした。そして，その 濃度は洗浄廃水の濃度と等しい $80 \mathrm{ppm}$ とし, $\mathrm{pH}$ 8 に調整した。な特，COD に基ついた活性炭吸着プ 
Table 2 Lignin, COD and BOD removals for caustic soda extract wastewater by activated sludge treatment, followed by lime treatment

\begin{tabular}{|c|c|c|c|c|c|c|}
\hline & $\mathrm{ppm}$ & $\begin{array}{l}\text { BOD } \\
\text { Removal }(\%)\end{array}$ & $\mathrm{ppm}$ & $\begin{array}{l}\text { COD } \\
\text { Removal (\%) }\end{array}$ & $\mathrm{ppm}$ & $\begin{array}{l}\text { Lignin } \\
\text { Removal }(\%)\end{array}$ \\
\hline Original wastewater & 170 & & 517 & & 455 & \\
\hline $\begin{array}{l}\text { Treated water by activated } \\
\text { sludge }\end{array}$ & 10 & 94 & 347 & 33 & 342 & 25 \\
\hline $\begin{array}{l}\text { Treated water by activated } \\
\text { sludge, followed by lime }\end{array}$ & & & 52 & 85 & 58 & 83 \\
\hline
\end{tabular}

Activated sludge treatment: sludge loading $0.24 \mathrm{~kg} / \mathrm{kg} \cdot \mathrm{MLSS} \cdot$ day, aeration time $5.5 \mathrm{hr}$ Lime treatment: $\mathrm{Ca}(\mathrm{OH})_{2}$ dosage $3 \mathrm{~g} / l$

ラント試験の結果との関連性を検討するために，洗浄 廃水拉よび洗浄廃水の前処理水について, 同一 COD

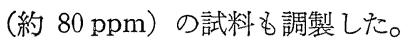

\section{1) 洗浄廃水}

黒液を希勫し， $0.45 \mu$ メンブランフィルターで沪過 したものを使用した。

2) 洗浄廃水の前処理水

黒液を適当に希釈した試料（リグニン濃度 $920 \mathrm{ppm}$ ) $10 l$ に消石灰 $30 \mathrm{~g}$ を添加し，バイブローミキサーで 10 分間攪汼した後放置し, 得られた上澄液に炭酸ガス を通じて pH を9.6にし，析出した炭酸カルシウムは 沪過により除いた。消石灰によるリグニンの除去率は $74 \%$ であった。この前処理水を $0.45 \mu$ メンブランフィ ルターで沪過彴, 適当に希釈して吸着等温試験用試料 とした。

3）晒アルカリ抽出廃水

工場から採取した廃水を $0.45 \mu$ メブランフィルタ 一で沪過後，希勫して試料とした。

4) 晒アルカリ抽出廃水の前処理水

工場から採取した廃水（リグニン濃度 $570 \mathrm{ppm}$, COD $680 \mathrm{ppm}$ および BOD $330 \mathrm{ppm}) 10 l$ をポリ バケッにとり，馴養スラッジ $2 l$ と混合し，エアレー ションストーン 4 個で曝気しながら $20^{\circ} \mathrm{C} て ゙ 24$ 時間 処理を行なった後, 沪過により清澄液を得た。

この処理水に消石灰（添加量 $3 \mathrm{~g} / \mathrm{l}$ ・試料）を加之, ジャーテスターにより，100 rpm で 30 分間混合攪拌 した後静置し，上澄液を採取し，この液に炭酸ガスを 通じて $\mathrm{pH}$ を10.5 に調整し，生成した炭酸カルシウ ムを沈降させ沪過により除いた。この処理水（以下晒 アルカリ抽出廃水の前処理水とする）を $0.45 \mu$ メブ ランフィルターで沪過した後，試料とした。な抹，こ の前処理のうち，活性污泥処理により原水の BOD の $93 \%$, COD の 30\%特よびリグニンの 10\%が除去され, 消石灰処理により原水の リグニンの約 $60 \%$ が除去さ れた。
5) リグニン溶液

前報1,2) の結果と実際の廃水に就ける結果を比較す るために，前報で述べた方法によりリグニン溶液を調 製した。

\section{2 活性炭吸着プラント試験}

当所で行なっている廃水処理のフローシートを Fig. 1 に示す。このうち，活性炭吸着処理装置は Photo 1 に示すように, ステンレス製の吸着塔（内 径 $15 \mathrm{~cm}$, 高さ $200 \mathrm{~cm}$ ） 3 本からなる 2 系列があり， バルブの切替えにより上昇流执よび下降流のいずれも 可能である。各吸着塔に粒状活性炭を風乾量として 16〜17 kg，それぞれ充媜した。

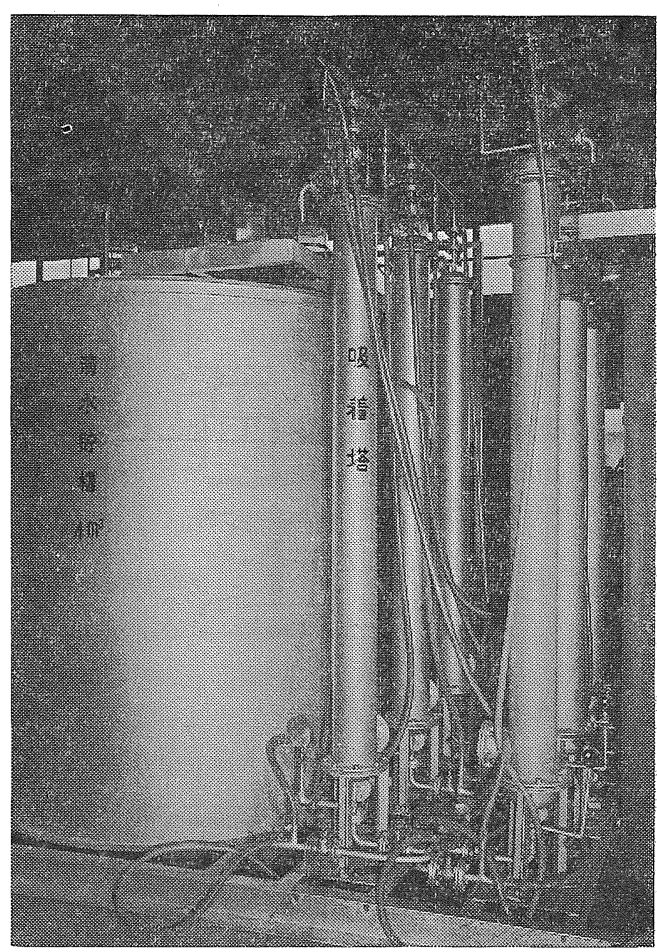

Photo 1 Pilot plant of adsorption system 

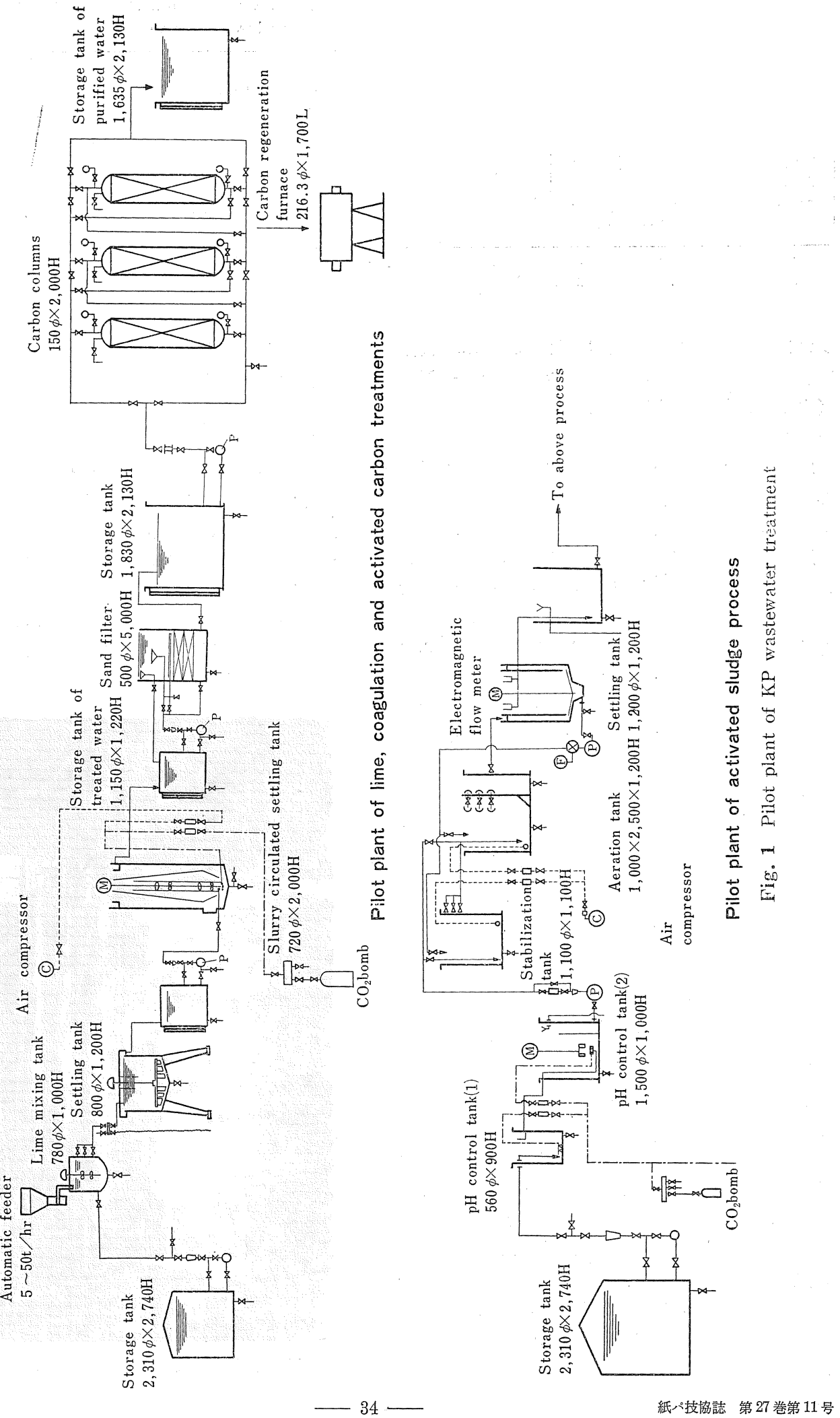
実験室に和村る基礎的研究の結果, リグニンの活性 炭への吸着速度が遅いことを認めたので，各廃水の活 性炭カラム吸着についても流量を $30 \mathrm{l} / \mathrm{hr}$ と小さくし， 吸着塔を 3 本シリーズに連結して下降流で通水した。 このときの空塔速度は $1.7 \mathrm{~m} / \mathrm{hr}$ であった。

\section{2,3 吸着等温試験}

各種廃水の吸着等温試験を行なうにあたり, 洗浄廃 水, 洗浄廃水の前処理水执よびリグニン溶液について, 吸着時間による吸着量の変化を調べた結果, 10 日間で 吸着量の変化は少なくなるが 30 日後まで増加が認の られ，特に洗浄廃水ではその後も吸着量の変化が認め られた ${ }^{5)}$ 。ただし，吸着速度試験は 14〜20メッシュ の活性炭を用い，活性炭の微粉化を極力避汗るために， 振とら培養機の振とう回数を 100 回/分にした。

今回は，活性炭吸着プラント試騟の結果と吸着等温 試験の関連性を検討すること劣目的としたので，すべ ての廃水について，活性炭添加量そ $0.1 \mathrm{~g}, 0.2 \mathrm{~g}, 0.3 \mathrm{~g}$ および $0.4 \mathrm{~g} の 4$ 種にし，10 日間吸着を行なわせた後， 見掛けの吸着等温線を求めた。

吸着等温試験操作は，100 $\mathrm{ml}$ 栓付三角フラスコに 所定量の活性炭を入れ, 蒸留水 $50 \mathrm{ml}$ を加えた後, デシケーターに入れて, 約 1 分間真空ポンプで引いて 減圧脱気し，そのまま 12 時間以上放置して活性炎の 細孔内を水で満たした。この試料に所定の濃度の廃水 試料 $50 \mathrm{~m} l$ を加兄て全液量を $100 \mathrm{ml}$ とし， $25^{\circ} \mathrm{C}$ の 振とう培養機に入れ，100回/分の振とう回数で 10 日 間吸着を行なわせた後, $0.45 \mu$ メンブランフィルター を用いた加圧沪過装置で沪過することにより微粉化し た活性炭を除き，沪液中の残存りグニン濃度，COD

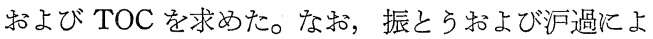
る濃度補正を行ならために，同時にブランク試験を行 なった。

\section{4 各種廃水のリグニン, $\mathrm{COD}$ および TOC の 測定}

リグニンは分子量分布を有し，分子量に応じて 280 $\mathrm{nm}$ に和忷る吸光係数が変わることが予想され，今回， 廃水試料として用いた洗浄廃水と晒アルカリ抽出廃水 に和忷るリグニンの分子量括よび分子構造の相違に関 する知見も得られている6)。さらに，洗浄廃水につい て，前処理（消石灰処理）を行なうことにより，原水 中のリグニンの高分子フラクションが選択的に除去さ れることが認められている7゙。

このよらなことから，各廃水中のリグニン濃度を正 確測定することほ困難と考光られるが，今回は，ク ラフトパルプ黒液から得られたリグニン溶液の 280 $\mathrm{nm}$ に特ける吸光度と濃度との関係をそのまますべて
の廃水に適用した。

COD 执よび TOC の測定法は前報 ${ }^{2)}$ と同棣である。

\section{3. 結果および考察}

\section{1 吸着等温試験}

\subsection{1 各種廃水のリグニン吸着等温線}

2.1.4 で述べた洗浄廃水, 洗浄廃水の前処理水, 晒 アルカリ抽出廃水，晒アルカリ抽出廃水の前処理水特 よびリグニン溶液について，リグニン濃度に基づいた 吸着等温線を求めた結果を Fig。2 示す。

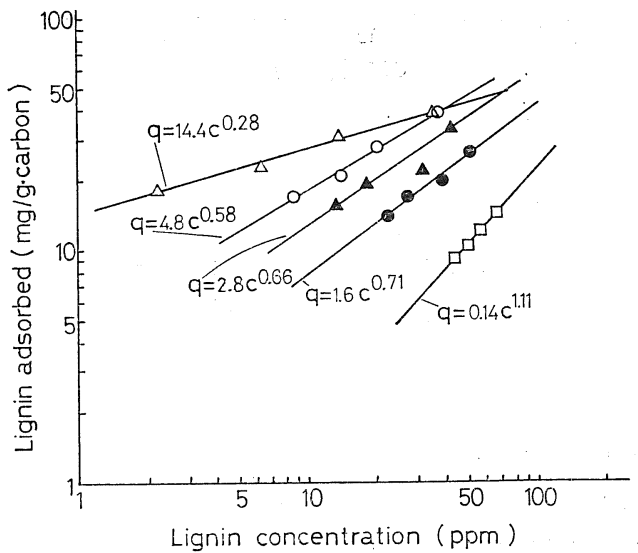

Fig. 2 Freundlich plots of adsorption isotherms for lignin

O: Lime-treated water of wash wastewater (Initial concentration $78.7 \mathrm{ppm}$ )

Wash wastewater

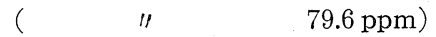

$\triangle$ : Pretreated water of caustic soda extract wastewater ( " $75.3 \mathrm{ppm}$ )

: Caustic soda extract wastewater ( " $\quad 76.0 \mathrm{ppm}$ )

$\square$ : Lignin solution

$$
\text { " } \quad 80.8 \mathrm{ppm})
$$

Fig.2 に示すよらにリグニン吸着量と残存濃度と は两対数グラフ上で直線関係にあり，Freundlich 式 が各吸着等温線に適応でき，各直線について Freundlich 式 $q=K C^{\frac{1}{n}}$ に和ける定数K抽よび $\frac{1}{n}$ 最小 2 乗 法によって求め，図中に示した。

Fig. 2 から，洗浄廃水执よび晒アルカリ抽出廃水 は前処理を行なうことにより，前処理水中のリグニン の活性炭に対する吸着性が増加していることが認めら れる。しかしながら，洗浄廃水では，前処理前後の吸

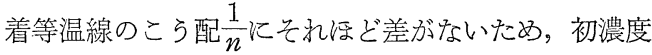
に沶いても両者の吸着量に大きな差があるのに齐し， 晒アルカリ抽出廃水では, 前処理前後の吸着等温線の こう配が 2 倍汪ど異なり，残存リグニン濃度が小さい 


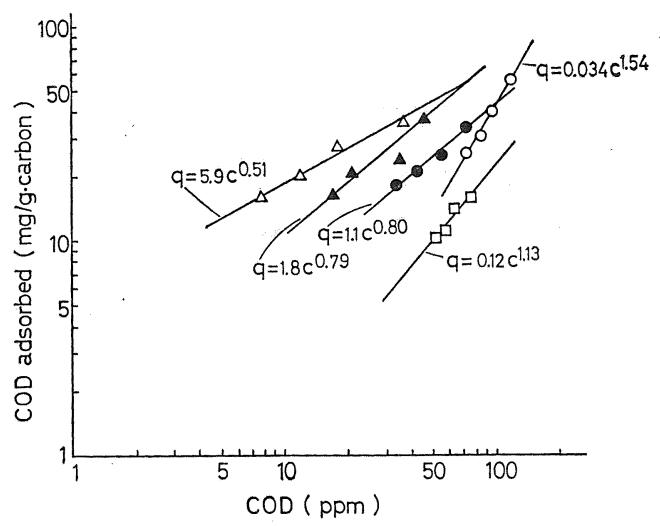

Fig. 3 Freundlich plots of adsorption isotherms for COD

Signs: the same as in Fig. 2

Initial concetration
: $177 \mathrm{ppm}$
웅 $107 \mathrm{ppm}$
$\triangle: 73 \mathrm{ppm}$
소 : $83 \mathrm{ppm}$
$\square: \quad 92 \mathrm{ppm}$

ときは両者の吸着量に大きな差があるが，初濃度に近 づくにつれて吸着量の差が小さくなり，初濃度のあた りで吸着量が一致している点が異なっている。

本報告で実際の廃水中のリグニンとしているものは $280 \mathrm{~nm}$ に吸収のある物質の総称であり，リグニン自 体にも分子量分布があり，吸着に関しては多成分混合 物と考岳られ。したがうて, 前処理により，280 nm に吸収を有する物質の割合に変化が生じ，そのために 前処理水の吸着等温線が異なっていると考学られるが， 今回はこれ以上検討しなかった。

リグニン溶液の吸着等温線は洗浄廃水の吸着等温線

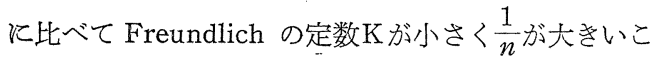
と，すなわら吸着性が低いことが喼められた。この点 については，リグニン溶液のリグニンが黒液を酸性に し，生成したリグニンであり，洗浄廃水中のリグニン の大部分を占めていると推定されることを考えると興 味深い。特そらく, 得られたリグニン試料の再溶解し たものと洗浄廃水中に特けるものとに化学的あるいは 物理的ななんらかの吸着性に相違を生じさせる変化が 生じたためと考光られる。ただし，リグニン溶液と洗 浄廃水は共に水溶液であるが，溶液中の無機成分の量 および質が異なっているので，この点も注意する必要 がある。

\subsection{2 各種廃水の COD 吸着等温線}

3.1 .1 で述べたリグニン吸着等温線を求めた溶液に ついて COD を測定し， COD 吸着等温線を作製した。

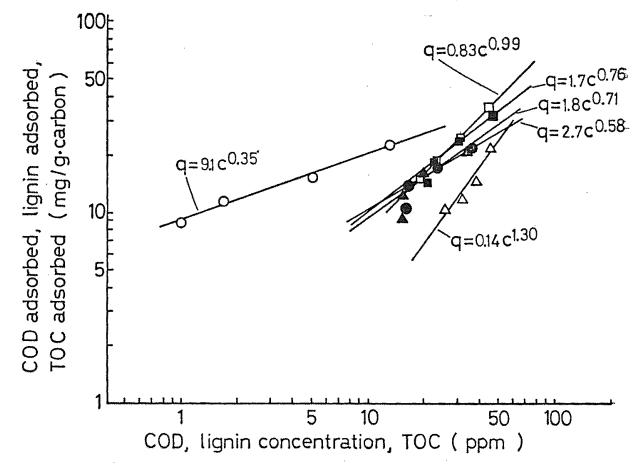

Fig. 4 Freundlich plots of adsorption isotherms

Lime-treated water of wash wastewater $\square$ : COD (Initial concentration $80.0 \mathrm{ppm}$ )
$\bigcirc$ : Lignin (
"I
$36.0 \mathrm{ppm})$
$\triangle:$ TOC
$67.4 \mathrm{ppm})$
Wash wastewater
闑: COD (Initial concentration $78.4 \mathrm{ppm}$ )
운: Lignin $58.2 \mathrm{ppm})$
A: TOC $52.8 \mathrm{ppm})$

その結果を Fig. 3 亿示す。各吸着等温線は Freundlich 式で表わすことができ，図中に示した。

Fig. 3 から，晒アルカリ抽出廃水については，前 処理を行ならことにより COD の吸着性は良くなるが, 洗浄廃水については，両者の吸着等温線が交差して和 り，残存濃度の大きいところでは前処理水の吸着量が 若干大きく，残存濃度が小さくなるにつれて吸着量は 逆に小さくなり，残存濃度 $10 \mathrm{ppm}$ では前処理水の吸 着量は洗浄廃水の $1 / 6$ である。各廃水試料の初濃度を 比較すると, 晒アルカリ抽出廃水については，未処理 水搞よび処理水の COD は，それぞれ 73 ppm 和よび $83 \mathrm{ppm}$ とよくにて抮り，前処理による吸着性の増加 は明らかであると考方られるが，洗浄廃水については， 未処理水の COD が $107 \mathrm{ppm}$ であるのに対し, 前処 理水の COD は $177 \mathrm{ppm}$ と初濃度が大きく異なって いる。このため, 初濃度の相違の吸着等温線に及洔す 影響の有無について検討した。

Fig。4 に同一 COD に和汗る洗浄廃水と洗浄廃水 の前処理水の吸着等温線を示した。リグニン特よび TOC に基づいた吸着等温線も同時に示した。Fig.4 に示されるよらに，COD 初濃度が同じであれば，両 廃水の吸着等温線の傾向は Fig. 3 の場合と似ている が，両者の吸着量にはそれほど大きな差はなく，洗浄 廃水を前処理しても吸着性はそれ活ど変化しないと考 兄れる。

Fig. 3 㸱よび 4 を比較することにより，COD吸着 
等温線が初濃度によって異なることが認められる。今 回は，10日間吸着に和ける見掛けの吸着等温線を求 めたものであるが，長時間吸着させてもこの傾向は変 わらないと推定され，異なる濃度の廃水の活性炭に対 する吸着性を検討する場合，それぞれの濃度に括忷る 吸着等温線を求めて比較する必要があると考兄られる。 $\mathrm{COD}$ 吸着等温線で比較した場合も，リグニン溶液 の吸着性が最低であることが認められた。

\section{3，1，3 各種廃水の TOC 吸着等温線}

洗浄廃水抒よび晒アルカリ抽出廃水の有機物質のな かには，過マンガン酸カリウムによって酸化されにく いものがあると考兄られ，COD がすべての有機污染 物質を示しているとはいいがたい。そこで，すべての 有機物質を表わす指標として TOC を用い，TOC 吸 着等温線を求めた。その結果を Fig. 5 亿示す。TOC 飞ついても COD の場合と同様, 初濃度が各廃水によ り異なっている。

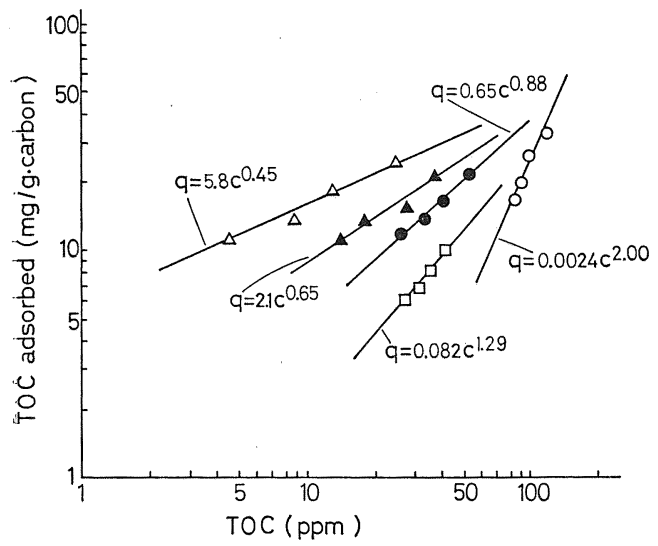

Fig. 5 Freundlich plots of adsorption isotherms for TOC

Signs: the same as in Fig. 2 Initial concentration

\begin{tabular}{|c|c|}
\hline$\bigcirc: 151 \mathrm{ppm}$ & \\
\hline$\triangle: \quad 49.8 \mathrm{ppm}$ & A: \\
\hline
\end{tabular}

Fig. 4 和よび 5 亿和ける洗浄廃水特よび洗浄廃水 の前処理水の TOC 吸着等温線を比較すると大きく異 なって括り，初濃度による影響が顕著である。したが って，明確には断定できないが，晒アルカリ抽出廃水 については，前処理を行ならことにより处理水の活性 炭に対する吸着性は若干よくなるが，洗浄廃水につい ては，逆若干悪くなると推定される。

\section{2 活性炭吸着処理のプラント試験}

\section{2.1 洗浄廃水の前処理水および洗浄廃水の希釈 水}

2.1.2 飞述べた洗浄廃水の前処理水を活性炭吸着 プラント試験に供し， 5 カ月あまり通水試験を行なっ た。その期間中適当な間隔で各塔からサンプリングを 行ない，リグニン拉よび COD を測定して破過曲線を 求めた。Fig. 6, 7 亿その結果を示す。参考のため, 活性炭吸着カラムに供給される前処理水の吸着質濃度 の変化を図中に示す。この変化は主に前処理前の原水 の吸着質濃度の変化汇起因する。

Fig. 6 は洗浄廃水の前処理水のリグニン破過曲線 であり，リグニンは洗浄廃水中の COD 成分の主なる のであり，消石灰に上る前処理水中にも相当量残って いると考觉られ，また廃水中の主たる着色物質である。

リグニンの測定は分光光度計により $280 \mathrm{~nm}$ の吸光 度を求めることにより，比較的簡単に行ならことが可

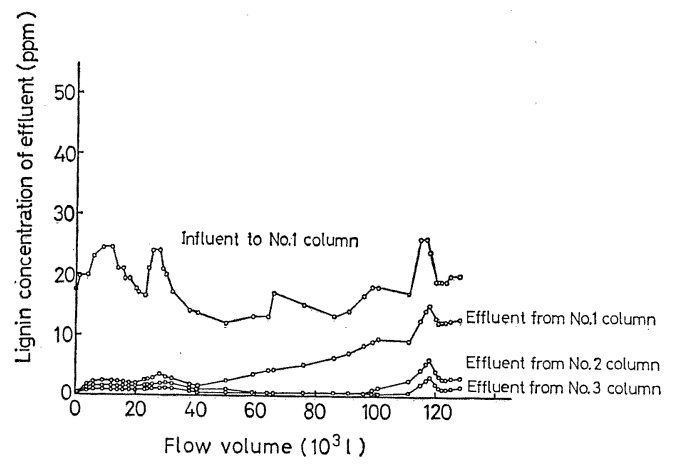

Fig. 6 Lignin breakthrough curves of limetreated water of wash wastewater

Experimental conditions: flow rate $31 \mathrm{l} / \mathrm{hr}$, superficial velocity $1.7 \mathrm{~m} / \mathrm{hr}$, carbon in column (air-dried weight) 17kg per column

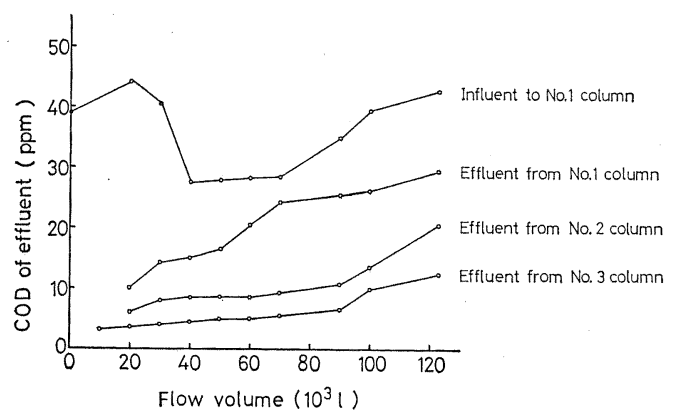

Fig. 7 COD breakthrough curves of limetreated water of wash waste water

Experimental conditions: the same as in Fig. 6 
能であり，廃水処理プロセス中に組みこんで自動的に 測定することも可能と考えられ，リグニン濃度による パルプ廃水処理の自動管理化が行なえるならば, COD あるいは TOC などによる管理よりも簡便と考えられ る。このような点からりグニン破過曲線を求めた。

Fig.6 の破過曲線に执いて，最初各塔に和ける流 出水のリグニン濃度が多少変動し，流出水量 $40,000 l$ あたりから，1本目の塔の流出水のリグニン濃度はし だいに高くなり，2 塔新よび 3 塔に和ける流出水のリ グシン濃度はむしろ低くなり，いずれも $1 \mathrm{ppm}$ 以下 で一定になっている。最初，リグニン濃度が変動した のは，活性炭細孔の脱気が十分でなく，細孔内へのリ グニンの拡散が十分でなかったためと考えられる。

当所の目標である廃水の用水化を考慮した場合，予 備実験の結果より，リグニン濃度 $2 \mathrm{ppm}$ であれば， COD 和よび色度がそれぞれ $15 \mathrm{ppm}$ および 20 以下 であると推定され，処理水は用水として再使用可能と 考えられるので, リグニン破過曲線の破過点を $2 \mathrm{ppm}$ と定め，活性炭吸着により得られる処理水量和よび 処理倍量を，各吸着塔について求めた。その結果を Table 3 に示す。本プラント試験に执いて，3本目 の吸着塔に特ける梳出水のリグニン濃度は $2 \mathrm{ppm}$ に 達していなかったが，試験の都合上，途中で中止した。

Table 3 Results of pilot plant test for activated carbon adsorption on the basis of lignin breakthrough curves

\begin{tabular}{|l|r|r|r|}
\hline Column No. & 1 & 2 & 3 \\
\hline Contact time (min) & 69 & 138 & 207 \\
\hline $\begin{array}{c}\text { Volume of effluent*1 } \\
\left(10^{3} l\right)\end{array}$ & 46 & 120 & $\begin{array}{r}\text { Above } \\
130\end{array}$ \\
\hline $\begin{array}{c}\text { Carbon usage*2 } \\
(l / \mathrm{kg} \cdot \text { air-dried carbon) }\end{array}$ & 2,710 & 3,530 & - \\
\hline
\end{tabular}

* 1 Volume of effluent is flow volume at the breakthrough point corresponding to 2 ppm lignin concentration of effluent

* 2 Corbon usage is in terms of volume of effluent per weight of carbon

Table 3 より，2本目の吸着塔に打ける接触時間 138 分で, $3,530 \mathrm{l} / \mathrm{kg}$ ・風乾活性炭の処理倍量が得ら れた。

Fig. 7 は前処理水の COD 破過曲線であり，Fig. 6 と比較するとき，カラムへの流入水の COD 25〜44 ppm は, リグニン濃度 $12 \sim 26 \mathrm{ppm}$ に比べて約 2 倍 であるが，各カラムの流出水の COD とリグニンの比 ははるかに大きく，2荅拉よび 3 塔に拈いては，試験 範囲内で 5 10 倍である。このことはリグニン以外の
COD 成分のちち，活性炭に吸着されにくいものが存 在することを示していると考えられる。

COD を用水化の指標にする場合, 当所では COD $12 \mathrm{ppm}$ を目標としたが，本報告では COD $15 \mathrm{ppm}$ とした。Fig.7に和いて, 破過曲線の破過点を $15 \mathrm{ppm}$ とした場合の各吸着塔に和ける処理水量和よび処理倍 量を Table 4 に示导。

Table 4 Retults of pilot plant test for activated carbon adsorption on the basis of COD breakthrough curves

\begin{tabular}{|l|r|r|r|}
\hline Column No. & 1 & 2 & 3 \\
\hline Contact time (min) & 69 & 138 & 207 \\
\hline $\begin{array}{c}\text { Volume of effluent* } \\
\left(10^{3} l\right)\end{array}$ & 40 & 105 & $\begin{array}{r}\text { Above } \\
120\end{array}$ \\
\hline $\begin{array}{c}\text { Carbon usage } \\
(l / \mathrm{kg} \cdot \text { air-dried carbon })\end{array}$ & 2,350 & 3,090 & - \\
\hline
\end{tabular}

* Volume of effluent is flow volume at the breakthrough point corresponding to $15 \mathrm{ppm} \mathrm{COD}$ of effluent

Table 4 より，2本目の吸着荅に括ける処理倍量 は $3,090 \mathrm{l} / \mathrm{kg}$ ・風乾活性炭であり, Table 3 のリグ ニン濃度に基ついた処理倍量の $87 \%$ である。

つぎに，洗浄廃水を希釈し，希翻水のリグニン濃度 を, 洗浄廃水の前処理水のリグニン濃度の平均值に近 い $20 \mathrm{ppm}$ とし，前処理水の場合と同様な条件で， およそ4カ月間吸着プラント試験を行なった。な和， 希釈水の COD は 27〜31 ppm の範囲に変動した。

Fig。 8，9 にそれぞれリグニン濃度执よび COD に 基づた破過曲線を示高。

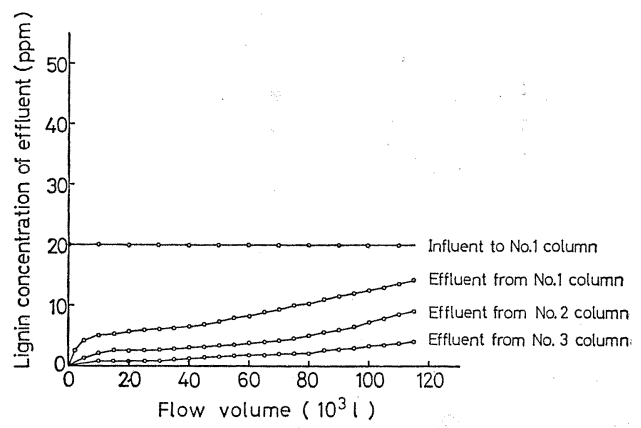

Fig. 8 Lignin breakthrough curves of dilute water of wash wastewater

Experimental conditions: flow rate $30 \mathrm{l} / \mathrm{hr}$, superficial velocity $1.7 \mathrm{~m} / \mathrm{hr}$, carbon in column (air-dried weight) $16.3 \mathrm{~kg}$ per column 


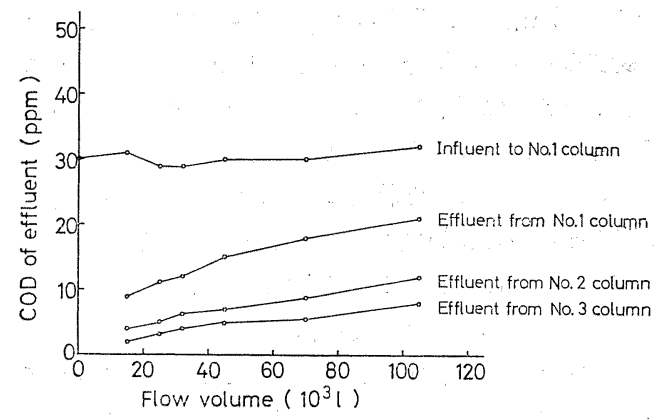

Fig. 9 COD breakthrough curves of dilute water of wath wastewater

Experimental conditions: the same as in Fig. 8

Table 5 Results of pilot plant test for activated carbon adsorption on the basis of lignin breakthrough curves

\begin{tabular}{|l|r|r|r|}
\hline Column No. & 1 & 2 & 3 \\
\hline Contact time (min) & 71 & 141 & 212 \\
\hline Volume of effuent* & 2 & 10 & 70 \\
\hline $\begin{array}{l}\text { Carbon usage } \\
(l / \mathrm{kg} \cdot \text { air-dried carbon) }\end{array}$ & 120 & 310 & 1,430 \\
\hline
\end{tabular}

* The same as in Table 3

Fig. 8 に和いて，前処理水の場合之同様，破過点 をリグニン濃度 $2 \mathrm{ppm}$ とした場合の 処理水量および 処理倍量を Table 5 亿示す。

Table 5 の結果を Table 3 に示した前処理水の結 果と同一接触時間に和ける処理倍量で比較すると，接 触時間 70 分では 1/27，140 分では 1/12，210 分では $1 / 3 \sim 1 / 4$ (推定値) といらように前処理水に比較し少 ない。

Fig. 2 のリグニン吸着等温線より，リグニン濃度 $20 \mathrm{ppm}$ に扣ける吸着量を求めると, 洗浄廃水では 13 $\mathrm{mg} / \mathrm{g}$ ・活性炭，洗浄廃水の前処理水では $27 \mathrm{mg} / \mathrm{g}$ ・ 活性炭であり, 洗浄廃水の吸着量は前処理水の $1 / 2$ で あり，吸着等温線から推定される洗浄廃水の処理倍量 は前処理水の $1 / 2$ となり，プラント試験に拉ける処理 倍量の比も接触時間が大きくなるにつれてこの值に近 ついて抽り，吸着等温線の比較から，プラント試験の 結果を推定することが可能と考えられる。

な输，3本目の吸着塔からの流出水は，最初無色透 明であるが，乙だいに着色し，リグニン濃度 $2 \mathrm{ppm}$ になると流出水貯槽中の水は淡黒褐色を示すことを認 めた。この点, 前処理水の活性炭吸着処理では, リグ
ニン濃度 $2 \mathrm{ppm}$ になっても流出水は無色透明であっ た。

Fig. 9 は洗浄廃水の COD 破過曲線であり，破過 点を $15 \mathrm{ppm}$ とした場合の処理水量叔よび処理倍量を Table 6 に示す。Table 4 の前処理水の結果と比較 するとき，同一接触時間に打汗る処理倍量は洗浄廃水 のほうが若干多いが，ほとんど差がないと考光られる。

Table 6 Results of pilot plant test for activated carbon adsorption on the basis of COD breakthrough curves

\begin{tabular}{|c|c|c|c|}
\hline Column No. & 1 & 2 & 3 \\
\hline Contact time $(\mathrm{min})$ & 71 & 141 & 212 \\
\hline $\begin{array}{l}\text { Volume of effluent* } \\
\left(10^{3} l\right)\end{array}$ & 45 & $\begin{array}{c}120 \\
\text { (Esti- } \\
\text { mated) }\end{array}$ & $\begin{array}{l}\text { Above } 120 \\
\text { (Esti- } \\
\text { mated) }\end{array}$ \\
\hline $\begin{array}{l}\text { Carbon usage }(l / \mathrm{kg} \cdot \\
\text { air-dried carbon })\end{array}$ & 2,760 & $\begin{array}{l}3,670 \\
\text { (Esti- } \\
\text { mated) }\end{array}$ & - \\
\hline
\end{tabular}

* The same as in Table 4

$\mathrm{COD}$ 吸着等温線から，カラム吸着に扎ける，洗浄 廃水和よび洗浄廃水の前処理水の処理倍量を相対的に 推定する場合，Fig。3 の吸着等温線を用いると，洗 浄廃水の COD $30 \mathrm{ppm}$ に和方る吸着量は $16.7 \mathrm{mg} / \mathrm{g}$ ・ 活性炎であるのに詨し，洗浄廃水の前処理水の COD $35 \mathrm{ppm}$ に抢汗る吸着量は $8.1 \mathrm{mg} / \mathrm{g}$ ・活性炭であり, 洗浄廃水の吸着量が 2 倍注ど大きく，乙たがって，処 理倍量も洗浄廃水が 2 倍注ど太きいことになる。一方, Fig. 4 の同一 COD 初濃度に叔ける吸着等温線より。 同様にして吸着量を求めると, 洗浄廃水では $22.5 \mathrm{mg} /$ $\mathrm{g}$ ・活性炭，洗浄廃水の前処理水では $28.0 \mathrm{mg} / \mathrm{g}$ ・活 性炭となり，前処理水の処理倍量が若干大さいことに なる。

活性炭吸着プラント試験では，ほぼ同じ処理倍量が 得られて叔り，Fig。4 の同一 COD 飞拈ける吸着等 温線でもって吸着量を比較するほうが妥当であると考 党られる。したがって，カラム吸着試験の結果学吸着 等温線で評価する場合は，カラム試験に使用した試料 と同じ濃度の試料による吸着等温線を求めて比較する のが適当であると考えられる。

以上の結果，洗浄廃水の消石灰処理の吸着性に関す る効果は，色度の主成分であるリグニンについては明 らかに認められるが，COD 成分についてはほとんど 変わらないと考えられる。しかしながら，廃水処理二 スト面から考劣るならば，洗浄廃水を直接活性炭吸着 処理する場合と，消石灰処理を行なった後低吸着質濃 度の処理水を活性炭吸着処理する場合の比較となり， 
後者の工程のほうが低コストと推定されるが，詳しい 計算については今後検討する予定である。

\subsection{2 晒アルカリ抽出廃水の前処理水}

2. 1.3 に述べた前処理水について, 洗浄廃水の場 合と同じ条件で 40 日間活性炭吸着プラント試験を行 なった。Fig.10 ヒリグニン破過曲線を示す。リグニ ン濃度 $2 \mathrm{ppm}$ 学破過点とした場合の処理水量和よび 処理倍量を Table 7 に示す。

Table 7 上り, 晒アルカリ抽出廃水の前処理水の, 各接触時間比括将る処理倍量は，洗浄廃水の前処理水 と比較し，きかめて少ないことが認められる。

Table 7 Results of pilot plant test for activated carbon adsorption on the basis of lignin breakthrough curves

\begin{tabular}{|l|c|c|c|}
\hline Column No. & \multicolumn{1}{|c|}{1} & \multicolumn{1}{|c|}{2} & \multicolumn{1}{|c|}{3} \\
\hline Contact time (min) & 71 & 142 & 213 \\
\hline $\begin{array}{l}\text { Volume of effluent* } \\
\left(10^{3} l\right)\end{array}$ & 1.7 & 4.5 & 15 \\
\hline $\begin{array}{l}\text { Carbon usage } \\
(l / \mathrm{kg} \cdot \text { air-dried carbon) }\end{array}$ & 100 & 130 & 290 \\
\hline
\end{tabular}

* The same as in Table 3

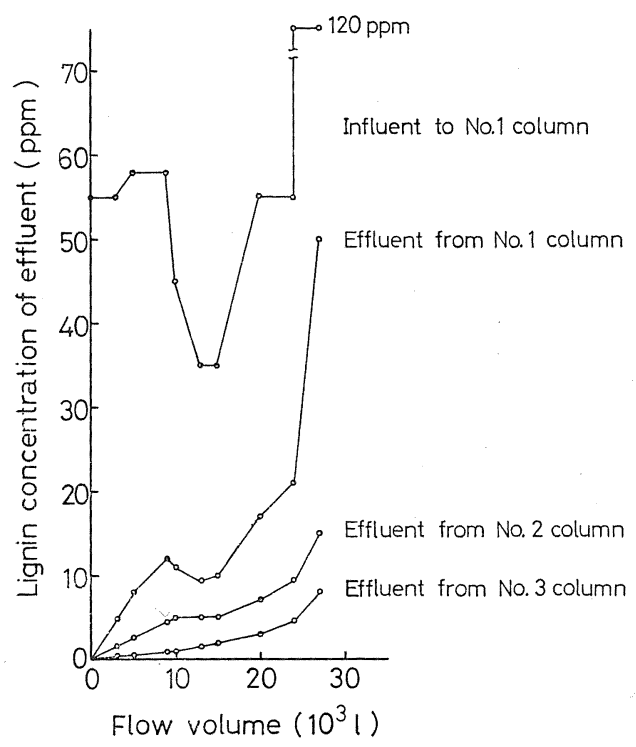

Fig. 10 Lignin breakthrough curves of pretreated water of caustic soda extract wastewater

Experimental conditions: flow rate $30 \mathrm{l} / \mathrm{hr}$, superficial velocity $1.7 \mathrm{~m} / \mathrm{hr}$, carbon in column (air-dried weight) 17kg per column
一方，Fig. 2 あるいは 4 のリグニン吸着等温線で 比較するとき, 洗浄廃水の前処理水の濃度 $20 \mathrm{ppm}$ 飞 执沙る吸着量は，晒アルカリ抽出廃水の前処理水の濃 度 50 ppm に抢兴着量より小さいことは明らかで ある。したがって，理論的炕，晒アルカリ抽出廃水 の前処理水の処理倍量が多くなるはずである。

晒アルカリ抽出廃水の前処理水の活性炭吸着プラン 卜試験で得られた少ない処理倍量は, 前処理水のリグ ニン濃度 $33 \sim 120 \mathrm{ppm}$ と洗浄廃水の 前処理水のリグ ニン濃度 $12 \sim 26 \mathrm{ppm}$ の相違, すなわち, 晒アルカリ 抽出廃水の前処理水の吸着に対する負荷が大さいこと 㳊起因すると推定されるが，洗浄廃水の前処理水之晒 アルカリ抽出廃水の前処理水中のリグニンの分子量拧 よび分子構造の相違の影響についても考虑する必要が ある。

\section{4. 総括}

本研究は, クラフトパルプ工場の洗浄廃水拉よび晒 アルカリ抽出廃水対象とし, 各廃水の活性炭吸着処 理による清水化の経済性を検討するための基礎資料を 得ることを目的とし，各廃水にそれぞれ適当な前処理 を行なった後, 中間プラント規模の試験装置により, 活性炭吸着処理を実施し, 処理倍量を求めた。

一方, 前処理の活性炭吸着処理に及ぼす効果和よび リグニン， COD 和よび TOC 飞基づいた各廃水の吸 着性を，見掛けの吸着等温線により検討し，さらに， 活性炭吸着プラント試験の結果と吸着等温線の関連性 について検討した。

その結果はつぎのと括りである。

1）各種廃水のリグニン吸着等温線より，洗浄廃水与 よび晒アルカリ抽出廃水のリグニンは，前処理によ って活性炭に対する吸着性が増加するが，前者では， 前処理前後の吸着等温線はほぼ平行に近い関係にあ るのに，後者では，初濃度に近づくにつれて吸着量 の差が小さくなる点が異なっている。また，各種廃 水のらちで, リグニン溶液のリグニンの吸着性が最 低であることが認められた。

2）各種廃水の COD 㧊よび TOC 吸着等温線につい ては，今回初濃度を一定にしなかったため明確には 結論できないが，晒アルカリ抽出廃水については， 前処理により吸着量が増大するが，洗浄廃水につい ては, 前処理による効果は少ないと推定される。

3）洗浄廃水の前処理水（リグニン濃度 $12 \sim 26 \mathrm{ppm}$, COD 25〜 44 ppm) 特よび洗浄廃水（リグニン濃度 $20 \mathrm{ppm}, \mathrm{COD} 27 \sim 31 \mathrm{ppm})$ 飞ついて, 空塔速度 $1.7 \mathrm{~m} / \mathrm{hr}$ で, 活性炭吸着プラント試験を行なった 
結果，接触時間約 140 分飞おいて，前者のリグニン および COD をそれぞれ破過点の指標とした場合の 処理倍量はそれぞれ $3,530 \mathrm{l} / \mathrm{kg}$ ・風乾活性炭沶よび $3,090 \mathrm{l} / \mathrm{kg}$ ・風乾活性炭であるのに対し，後者の 処理倍量はそれぞれ $310 \mathrm{l} / \mathrm{kg} ・$ 風乾活性炭揖よび $3,670 \mathrm{l} / \mathrm{kg}$ ・風乾活性炭 (推定值)であった。この結 果は, 洗浄廃水の前処理水特よび洗浄廃水の吸着等 温線に和ける吸着量から求めた処理倍量の比と比較 的一致して括り，吸着等温線の比較から，力ラム試 験の結果を推定することが可能と考えられる。

4）晒アルカリ抽出廃水の前処理水（リグニン濃度 33 １20 ppm）の処理倍量は，洗浄廃水之同一の吸着 試験条件に和いて接触時間約 140 分で， $130 \mathrm{l} / \mathrm{kg}$ ・ 風乾活性炭と非常に少なかった。吸着等温線から推 定すると，洗浄廃水の前処理水と同じ程度の処理倍 量が得られるものと考光られる。したがって，この ように処理倍量が少ないのは，両前処理水の濃度の 相違によると推定されるが，COD について今回測 定していないこと执よび晒アルカリ抽出廃水の前処 理水特よび洗浄廃水の前処理水中のリグニンの分子 量和よび分子構造の相違などが考えられることから，
今後，さらに検討する必要がある。

終りに，本研究を行なうにあたり，懇切なご指導を 賜わりました当所の前所長 生源寺廷氏に深謝すると ともに活性污泥処理を担当していただいた，当所の赤 松 勲，上嶋·洋両技官执よび消石灰処理を担当して いただいた，当所の加藤俊作，久保隆昌両技官に深謝 する。

\section{文献}

1) 壁谷 洋, 藤井利郎, 久保隆昌, 木村 裕, 浦野 紘平，紙八゚技協誌，26，125（1972）

2）壁谷 洋，藤井利郎，木村 裕, 紙パ技協誌，投 稿中

3）赤松 勲, 上嶋 洋, 紙パ技協誌, 25, 569 (1971); 26, 224 (1972)

4）加藤俊作，久保隆昌，木村 裕，日本化学会九州 支部常会講演要旨 C. 11 (1971)

5）壁谷 洋，藤井利郎，木村 裕，未発表データ

6）鮫島一彦，近藤民雄，木材学会誌，16，347 (1970)

7）加藤俊作，久保隆昌，木村 裕，日本化学会中国 四国支部合同高知大会講演要旨 B. 18 (1971)

\section{紙パ技協誌へ \\ 広告揭載の予願い}

紙パ技協誌は業界唯一の技術雑誌で 毎月全会員に配布 されております

創刊以来 広告掲載を賜っておりますスポンサ一各位には 大変好評を博しており技術誌の強味を示しております

広告は是非本誌をご利用下さい

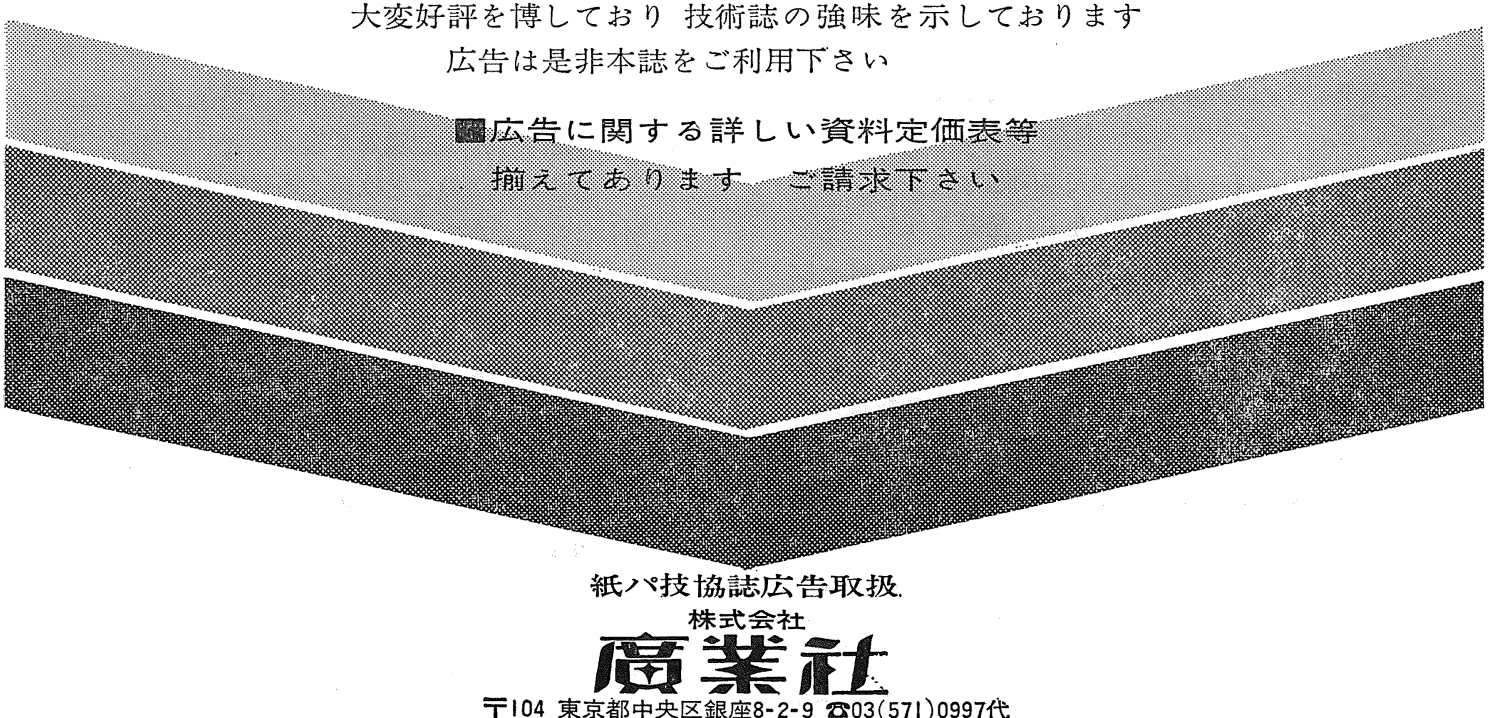

F104 東京都中央区銀座8-2-9 2003 (571)0997代 